García Martínez, Pedro.

Profesor contratado doctor, Universidad Politécnica de Cartagena, Departamento de Arquitectura y Tecnología de la Edificación, grupo de investigación GRAMMAR.

\title{
El canon are-bure-boke: una conexión contemporánea entre fotografía, arquitectura y filosofía; una conexión entre Japón y Francia.
}

\section{The canon are-bure-boke: a contemporary connection between photography, architecture and philosophy; a connection between Japan and France.}

TIPO DE TRABAJO:

Comunicación

PALABRAS CLAVE:

Japón, Francia, Provoke, arquitectura, fotografía.

KEY WORDS:

Japan, France, Provoke, architecture, photography, philosophy.

RESUMEN.

En los escritos de arquitectos japoneses como Toyo Ito y Kazuyo Sejima es relativamente frecuente encontrar términos empleados por autores posestructuralistas franceses como Deleuze y Guattari. El texto pretende ahondar en algunos de los hechos que explicitan esta relación. Para ello, la investigación se centra en la figura de Koji Taki y su participación en la revista Provoke donde contribuyó a la ideación del canon estético "are-bure-boke", en cuya formulación se encuentran intereses compartidos con los mencionados autores. La posterior relación de Taki con Ito y Sejima permite cerrar el círculo relacional planteado.

ABSTRACT

In the writings of Japanese architects Kazuyo Sejima and Toyo Ito is relatively common to find terms used by French poststructuralist authors such as Deleuze and Guattari. The text aims to delve into some of the facts that specify this relationship. For this, the research focuses on the figure of Koji Taki and his participation in the magazine Provoke where he helped ideation aesthetic canon "are-bure-boke". In its formulation, this canon shares some ideas with the approach of the mentioned authors. Taki subsequent relationship with Ito and Sejima closes the circle relational raised. 